\title{
Identity, Belonging and Solidarity among Russian-speaking Queer Migrants in Berlin
}

\author{
Richard C. M. Mole
}

International migration has emerged one of the key political issues of the past fifty years and has thus been the subject of a vast amount of academic research. In countless articles, books, and reports scholars have focused on the causes and consequences of migration with respect to the sending and receiving states and, to a lesser extent, on the lives of the migrants themselves. While the gendering of migration has been studied since the early 1990s, queer migration has only recently piqued academic interest. ${ }^{1}$ Nevertheless, a small but growing literature on migration by sexual minorities has emerged, comprising theoretical analyses of the relationship between migration and sexuality; studies of rural-to-urban domestic migration; border crossing by lesbian, gay, bisexual, trans, and queer (LGBTQ) migrants and the legal hurdles they have to overcome; the (re)construction of sexual identities following migration; and the emergence and lived experience of "queer diasporas."”

This research was made possible thanks to an Alexander von Humboldt Fellowship for Experienced Researchers.

1. See, for example, William T. Bielby and Denise D. Bielby, "I Will Follow Him: Family Ties, Gender-Role Beliefs, and Reluctance to Relocate for a Better Job," American Journal of Sociology 97, no. 5 (March, 1992): 1241-67; Gina Buijs, Migrant Women: Crossing Boundaries and Changing Identities (Oxford, 1993); Pierrette Hondagneu-Sotelo, Gendered Transitions: Mexican Experiences of Immigration (Berkeley, 1994).

2. As my aim is to examine the relationship between migration and sexuality, I will focus on LGBQ migrants given that trans is a gender and not a sexual identity. I also acknowledge that the terms "lesbian," "gay," "bisexual" and "queer" are not universally accepted or understood in the Russian context, with other terms, such as goluboy or tema often used instead. I am thus using "lesbian," "gay," "bisexual” and “queer” as categories of analysis, rather than assuming they are categories of practice. See: Jon Binnie, "Invisible Europeans: Sexual Citizenship in the New Europe," Environment and Planning A, 29, no. 2 (1997): $237-$ 48; Nicola Mai and Russell King, "Love, Sexuality and Migration: Mapping the Issue(s)," Mobilities, Special issue on Love, Sexuality and Migration 4, no. 3 (2009): 295-307; Martin F. Manalansan IV, “Queer Intersections: Sexuality and Gender in Migration Studies," International Migration Review 40, no. 1 (February, 2006): 224-49; Andrew Gorman-Murray, "Intimate Mobilities: Emotional Embodiment and Queer Migration," Social and Cultural Geography 10, no. 4 (2009): 441-60; Andrew Gorman-Murray, "Rethinking Queer Migration through the Body," Social and Cultural Geography, Special Issue on Lesbian Geographies 8, no. 1 (2007): 105-21; Lionel Cantú, Jr., The Sexuality of Migration: Border Crossings and Mexican Immigrant Men (New York, 2009); Eithne Luibhéid, "Sexuality, Migration and the Shifting Line between Legal and Illegal Status," GLQ: A Journal of Lesbian and Gay Studies 14, no. 2-3 (2008): 289-315; Eithne Luibhéid, Entry Denied: Controlling Sexuality at the Border (Minneapolis, 2002); Eithne Luibhéid and Lionel Cantú, Jr., eds., Queer Migrations: Sexuality, U.S. Citizenship, and Border Crossings (Minneapolis, 2005); Adi Kuntsman, Figurations of Violence and Belonging: Queerness, Migranthood and Nationalism in Cyberspace and Beyond (Oxford, 2009); David L. Eng, "Out Here and Over There: Queerness and Diaspora in Asian American Studies," Social Text, Special issue on Queer Transections of Race, Nation and Gender 52-53, vol. 15, no. 3-4 (Fall/Winter 1997): 31-52; Simon Watney, "AIDS and the Politics of Queer Diaspora," in Monica Dorenkamp and Richard Henke, eds., Negotiating Lesbian and Gay Subjects, (New York, 1995), 53-70; Martin F. Manalansan IV, Global Divas: Filipino Gay Men in the Diaspora (Durham, 2003). 
In geographical terms, however, this work focuses primarily on the United States, with some attention also paid to Asian and Latin American societies as sending countries. Far less research has been conducted on migration by LGBTQ individuals to or within Europe. This is surprising given the disparities in attitudes towards and the degree of legal protection for LGBTQ people across Europe and thus the extent to which differences in said attitudes and rights could potentially act as push or pull factors in sending and receiving states, respectively. ${ }^{3}$

Against this backdrop the aim of the article is to examine migration by LGBQ individuals from Russia and other post-Soviet states to the German capital of Berlin, with a view to exploring their motivations for migrating, choice of destination, integration strategies and relations with the Russianspeaking ethno-cultural diaspora, assessing the extent to which each of these processes was and is influenced by sexuality. The article also examines the potential benefit of using "queer diaspora" as a heuristic device to think about identity, belonging, and solidarity among sexual minorities in the context of dispersal and transnational networks. ${ }^{4}$

Following a brief explication of my methods and a theoretical discussion of migration and diaspora, I examine how homosexuality has been constructed in post-Soviet Russia, with a view to gaining a sense of the social environment in which the interview respondents, on the basis of whose lived experiences the analysis is based, grew up. I also seek to understand why attitudes towards sexual minorities have become more negative in recent years. This section will be followed by an analysis of the migration and integration strategies of Russian-speaking LGBQ migrants in Berlin, examining the role of both the ethno-cultural and queer diasporas.

\section{Methodology}

The qualitative research upon which this article is based is drawn from a larger project conducted in 2012-14 on LGBT migration from eastern Europe and Latin America to London and Berlin. Eligible respondents for this specific research were literate men and women aged eighteen years or over who self-identified as non-heterosexual migrants from Russia or one of the post-Soviet states and whose native language was Russian. The sample was recruited through dating and community websites on the Internet, community venues, and through snowballing. Informed consent was sought using information sheets in Russian, English, and German. In total, twenty-one in-depth interviews were conducted with Russian-speakers in Berlin. The interviewees were aged between twenty-one and thirty-six; ten were men and eleven were women. The interviews were carried out in Russian, English, or German depending on the preference of the interviewee, took place in a university office and lasted,

3. For information on legal equality for LGBTI citizens in Europe in 2015, see the ILGA-Europe Rainbow map: http://www.ilga-europe.org/sites/default/files/Attachments/ side_a_rainbow_europe_map_2015_a3_no_crops.pdf (last accessed May 10, 2015).

4. Anne-Marie Fortier, "Queer Diaspora," in Diane Richardson and Steven Seidman, eds., Handbook of Gay and Lesbian Studies (London, 2002), 184. 
on average, 45-50 minutes. Participants were offered twenty-five euros as an incentive. Purposive sampling was used for the interviews to ensure a gender balance but the sample does not otherwise claim to be representative. The interviews were recorded and transcribed verbatim. Data management and analysis were facilitated by the use of the qualitative software N-Vivo. The verbatim data was coded and ordered within a thematic matrix, which emerged both from reviewing extant literature and the interview data itself. N-Vivo helped to identify key themes in the respondents' narratives, around which the article has been structured: growing up LGBQ in their home countries, relationships with friends and family, social attitudes towards homosexuality, the decision to migrate and choice of destination, their relationships with members of their ethnic communities in Germany and with their families and friends at home, their national identities, and their lives as LGBQ in the destination society. Participant observation (subsequently, observer participation) was also conducted over a period of six months at the fortnightly meetings, social gatherings and activist events of Quarteera, an association of LGBT Russian-speakers and their friends. As a result of my attending the Quarteera meetings, I became friends with a number of its members. Being granted access to their private spheres allowed me to gain greater insight into their day-to-day lives as LGBQ migrants. In the article, pseudonyms have been used to protect participants' identities.

\section{Queering Migration and Diaspora}

The term "queer," when discussed with reference to individual subjects, is used here as an alternative for "lesbian," "gay" and "bisexual" to reflect the fact that the latter western terms were not adopted by all the migrants whom I interviewed. ${ }^{5}$ It is noteworthy that the very idea of "queer" was to a significant extent brought about by migration in that the mass movement of people to the west from various non-western cultures brought into sharp relief the numerous "sexual identity categories and practices that [did] not depend on Western conceptions of selfhood and community," thereby producing a range of queer identities and subjectivities. ${ }^{6}$ With reference to queer migration and queer diaspora, "queer" is used in part to take account of the queer subjects of the processes of migration and diaspora but also to refer to the ways in which the presence of non-heterosexuals problematizes hegemonic understandings of migration and diaspora. ${ }^{7}$

The hegemonic understanding of migration sees the main motivation as being economic, with individuals moving abroad to gain higher wages or acquire marketable skills. ${ }^{8}$ Research into migration by LGBQ individuals, however, while not discounting the economic motivation entirely, shows that

5. "Queer" is also used to refer to non-cisgender individuals, although trans migrants are not part of this research.

6. Martin F. Manalansan IV, "Queer intersections,” 229.

7. For an in-depth discussion of queer approaches in sociology, see Steven Seidman, ed., Queer Theory/Sociology (Cambridge, Mass., 1996).

8. Oded Stark and David E. Bloom, "The New Economics of Labor Migration," The American Economic Review 75, no. 2 (May 1985): 173-78. 
factors relating specifically to sexuality play an equal if not more important role in prompting them to relocate. In his ground-breaking study of queer migration within Australia, Andrew Gorman-Murray identifies three patterns of and motivations for "queer migration," which he relates exclusively to cases where "the needs or desires of non-heterosexual identities, practices, and performances" are implicated in the queer migrant's decision to move. ${ }^{9}$ The first is "coming-out migration," whereby LGBT individuals move for the purpose of "self-reinvention as non-heterosexual and to explore bodily sexual desires in the process"; the second is "gravitational group migration," that is, "moving to be near a neighbourhood with a gay and lesbian presence"; the third is "relationship migration," where individuals move "with a partner to consolidate a same-sex relationship-or conversely, moving away after relationship breakdown."10

Reference to a hegemonic understanding of diaspora is perhaps somewhat overstated, as the concept has been the subject of much academic debate, although one could argue that there is now greater consensus as to its key characteristics. The term "diaspora” initially referred exclusively to the scattering of the Jews following their exile in Babylon, before being broadened to include the dispersion inter alia of Greeks, Africans, and Armenians and was originally understood to constitute the "traumatic dispersal from an original homeland and the salience of the homeland in the collective memory of a forcibly dispersed group." 11 Accordingly, initial understandings of the concept were associated with the traumatic wrench from the homeland and "a historical experience of victimhood at the hands of a cruel oppressor." 12 However, by the early 1990s these key defining characteristics of diaspora were being challenged by scholars such as William Safran, who argued that the concept could be usefully applied to a broader range of expatriate communities, such as labor migrants, colonial migrants, and trade migrants, who left their homelands voluntarily. ${ }^{13}$ This more flexible understanding of diaspora cast the conceptual net much wider than before, resulting in what Robin Cohen subsequently referred to a "diaspora craze," whereby the term was applied to a wide range of communities, spaces, and practices. ${ }^{14}$ While greater awareness of the analytical benefit of "diaspora" could be seen as an encouraging development, the problem with casting the net so wide is that the concept becomes "stretched to the point of uselessness. . . . If everyone is diasporic, then no one is distinctively so." 15 Rogers Brubaker therefore called for the conceptualization of diaspora to be consolidated, insisting that communities would need to meet three criteria if they were to be considered diasporas: dispersion, homeland orientation, and boundary maintenance.

9. Andrew Gorman-Murray, “Intimate Mobilities,” 443.

10. Ibid., 446.

11. Robin Cohen, Global Diasporas: An Introduction (London, 2008), 4.

12. Ibid.

13. William Safran, "Diasporas in Modern Societies: Myths of Homeland and Return," Diaspora: A Journal of Transnational Studies 1, no.1 (Spring 1991): 83-99.

14. Cohen, Global Diasporas, 8.

15. Rogers Brubaker, “The 'Diaspora' Diaspora,” Ethnic and Racial Studies 28, no. 1 (2005), 3. 
Although some academics use diaspora to refer to settled communities living outside of the ethnic homeland as a result of shifting borders rather than physical relocation, dispersion is generally accepted as the sine qua non of diaspora. ${ }^{16}$ While there is some disagreement as to whether dispersion should be forced or also voluntary and whether people have to cross the state frontier or whether they could also be dispersed within the state, there is general agreement that members of a diasporic community should be scattered beyond the homeland.

The role of the homeland orientation in definitions of diaspora is more contentious. For Safran, the existence of diaspora is conditional on a very particular relationship with the homeland, one in which the latter is seen inter alia as "the true, ideal home and as the place to which one would (or should) eventually return." ${ }^{17}$ The focus on homeland orientation and, in particular, on the "teleology of return" has been criticized by many, however, with James Clifford pointing out that many members of the African diaspora, for example, would not necessarily know to which homeland they should return. ${ }^{18}$ The same, one could argue, is true of migrants from states such as the Soviet Union, which no longer exists. Moreover, it has been argued that focusing on the homeland as the original source of the diaspora reinforces its primordial ethnic character and fails to take account of difference within the diaspora along lines of class, gender, and sexuality, let alone allowing for the possibility of diasporas to be formed around an identity other than the ethnic. ${ }^{19}$ Yet, while we could agree that "decentered, lateral connections may be as important as those formed around a teleology of origin/return," the identities underpinning the diaspora still derive, at least in part, from the identity of the original homeland. ${ }^{20}$ While they may be hybrid, hyphenated identities, the culture of the homeland-even if it is rejected-remains the key point of reference. ${ }^{21}$

Debates about the relative homogeneity or hybridity of diaspora identities also figure in the third of Brubaker's key conditions of diaspora: boundary-maintenance. Whether self-policed as a means to resist assimilation and safeguard the migrant community's original identity or religion, or externally imposed as part of a policy of segregation, maintaining a clear boundary between the migrant community and the host society is seen as a key condition of diaspora existence. Or at least it was in the past. As there is less pressure on migrants today to assimilate fully into the culture of the host society and as new technologies and cheap flights enable migrants to maintain inter-personal ties with the homeland, however, endogamy and unbending

16. See, for example, Myra A. Waterbury, "Internal Exclusion, External Inclusion: Diaspora Politics and Party-Building Strategies in Post-Communist Hungary," East European Politics and Societies 20, no. 3 (2006): 483-515.

17. William Safran, "Diasporas in Modern Societies," 83-84.

18. James Clifford, "Diasporas," Cultural Anthropology 9, no. 3 (August 1994), 305.

19. Floya Anthias, "Evaluating 'Diaspora': Beyond Ethnicity?," Sociology 32, no. 3 (1998), 557.

20. James Clifford, "Diasporas,” 305-6.

21. See Stuart Hall, "Cultural Identity and Diaspora,” in James Rutherford, ed., Identity: Community, Culture, Difference (London, 1990), 222-37. 
adherence to the cultural practices of the "old country" are no longer essential for the survival of the diasporic community. Historical experience has shown that incorporating elements of other cultures into its own does not signal the demise of a diaspora. The existence of a diaspora is therefore conditional not on rigid demarcation but on a sense of difference between the migrant community and the host society. As long as diasporas do not assimilate completely, cultural syncretism does not pose the threat to their continued existence it once did.

Decentering rigid boundary-maintenance and the teleology of origin/ return from the definition of diaspora, while nevertheless maintaining a distinct (perhaps hybrid) identity oriented towards the homeland (however understood) provides a degree of flexibility in the application of "diaspora" to individual cases, without losing cohesion in its conceptualization. Moreover, not only are the borders of diasporas not fixed but the idea that all members of a diaspora share a single identity is also not credible. When considering the contents of specific identities, it is important to remember that they are not given but "reflect the perceptions, priorities, and aspirations of those people who have the power to both construct categories and promote them as natural or superior." 22 What the leaders of a particular diasporic community may present as the one true representation of the national culture is therefore unlikely to chime with all members of the diaspora. At the very least, individuals will attach different meanings to the shared culture, precluding the possibility of a single, unified, shared identification.

This reconceptualization allows us to think of "diaspora" not solely as a rigidly-demarcated, bounded community, defined exclusively with reference to an ethnic homeland, with a shared identity and joint interests (although diasporic social forms of this kind clearly do exist at the micro level) but rather opens up a space for "diaspora" to be used flexibly and applied to migrant communities defined not solely in ethnic terms, while also recognizing that diasporic subjects are diverse inter alia in terms of their age, gender, class, political affiliation and, not least, sexuality.

The incorporation of sexuality into the study of diaspora has produced a number of works on "queer diaspora," although there is no consensus as to how best to understand the concept. Basing their analyses on a comparison with the ethno-cultural model and focusing on the scattering of diasporic subjects, sexuality scholars initially dismissed the very possibility of its existence as a social form in that it would have "no locale from which to wander." 23 Subsequent analyses understood the concept more as a form of consciousness, applying it to a feeling of exile, locating LGBQ individuals outside the "home" of the heterosexual family or the nation. ${ }^{24}$ The dispersal here is thus metaphorical, rather than physical. Stripping diaspora of its ethno-cultural content and decentering the original homeland as a defining feature, Simon

22. Jan Penrose and Richard C. M. Mole, "Nation-States and National Identity," in Kevin R. Cox, Murray Low, and Jennifer Robinson, eds., The SAGE Handbook of Political Geography (Los Angeles, 2008), 345.

23. Michael Warner, "Introduction," in Michael Warner, ed., Fear of a Queer Planet: Queer Politics and Social Theory (Minneapolis, 1993), xvii.

24. See David L. Eng, "Out Here and Over There" 31-52. 
Watney uses queer diaspora to refer to the diasporization of queer culture and politics, whereby queer diaspora is used metaphorically but also implies that the queer diaspora does exist as a social form:

Unlike the tendency of seventies and eighties lesbian and gay theory to
develop overly monolithic notions of identity and cultural politics, the con-
cept of diaspora is suggestive of diversification, of scattering, fracturing,
separate developments, and also, perhaps, a certain glamor. It also suggests
something of a collective interest, however difficult thus may be to pin down.
It implies a complex divided constituency, with varying degrees of power
and powerlessness. ${ }^{25}$

Problematizing the conceptualization of "queer diaspora" as the diasporization of queer, Anne-Marie Fortier understands it more as the queering of diaspora, whereby queer spaces are created "within ethnically-defined diasporas" in order to challenge "the heterosexist norms supporting definitions of ethnic diasporas." ${ }^{26}$ However the concept is understood, a shared motivation of scholars working in this field is to use "queer diaspora" as a heuristic device to think about identity, belonging, and solidarity among sexual minorities in the context of migration. ${ }^{27}$ Yet, to understand why migration is often seen as "a means of escape and of self-realization" in the first place for many queers and specifically my interview respondents, we need to understand how homosexuality has been constructed in post-Soviet Russia and why attitudes towards sexual minorities have become more negative in recent years. It is to these points I now turn.

\section{Homosexuality and Homophobia in Vladimir Putin's Russia}

While consenting sexual acts between men were decriminalized by the Duma in 1993, attitudes towards LGBQ individuals were slow to change and have recently taken a turn for the worse. ${ }^{28}$ Two decades on, homosexuality is still considered by many Russians to be an illness requiring medical treatment or the result of bad upbringing or sexual abuse, with only a small minority believing it to be a "sexual orientation from birth, which merits the same rights as heterosexual orientation." ${ }^{29}$ In the years between Putin's first and third presidencies, the percentage of Russians relating towards gays and lesbians kindly, calmly, or with interest has fallen from $47 \%$ to $29 \%$, while those relating to homosexuals with apprehension, annoyance, or disgust has increased from $48 \%$ to $65 \% .{ }^{30}$ Even before the introduction of the regional and federal laws banning the propaganda of non-traditional sexual relations, researchers found that-despite quite vibrant gay scenes in the larger Russian towns

25. Watney, 59.

26. Fortier, “Queer Diaspora," 183.

27. Ibid., 184.

28. Consenting sexual acts between adult women had never been specifically criminalized in Russia.

29. For detailed statistics on public opinion on homosexuality, see "Homophobia," press release of the Levada-Center, at http://www.levada.ru/eng/homophobia (last accessed September 2, 2015).

30. Ibid. 
and cities-few individuals identified themselves publicly as gay, lesbian, or bisexual. ${ }^{31}$ There was thus little sense of an LGBQ community existing in post-Soviet Russia. ${ }^{32}$ As discussed in the introduction to the themed section, sexual minorities were and are generally seen as not belonging and thus not deserving of full sexual citizenship and expected to remain invisible. ${ }^{33}$ While these processes can be traced back to the mid-1990s, it was at the start of Putin's third presidency in 2011 that a specific conceptualization of gender and sexuality was elevated to an issue of state policy, a process that would have negative consequences for sexual minorities. ${ }^{34}$

It was the mass protests against the falsification of the results of the 2011 presidential elections which prompted Putin to reaffirm his political legitimacy by protecting "traditional Russian values" in the face of alien ideas from the west, such as tolerance of homosexuality. ${ }^{35}$ Following a number of regional bills banning the spreading of "propaganda of non-traditional sexual relations," Putin signed the federal law on June 30, 2013, under the terms of which individuals and organizations can be fined for disseminating information about "non-traditional sexual orientations" among minors or for promoting "the social equivalence of traditional and non-traditional relationships." ${ }^{36}$

Appeals to tradition and "the symbolic resource of the collective past"legitimized by full support from the Russian Orthodox Church-provide Russian politicians with a "powerful lever for political mobilization" aimed at strengthening national unity in the face of perceived internal and external enemies. ${ }^{37}$ According to Cai Wilkinson, homophobia in Russia "functions as a Slavophile political shorthand for national identity and traditional values."38 The restriction of gay rights enables Putin to clamp down on actual and potential opponents, deflect attention from political and economic problems, and shore up support among the conservative majority. To ensure that traditional values/anti-LGBQ discourse resonates with Russian society, Putin frames it as

31. Francesca Stella, Lesbian Lives in Soviet and Post-Soviet Russia: Post-Socialism and Gendered Sexualities (New York, 2015), 110-25.

32. See Laurie Essig, Queer in Russia: A Story of Sex, Self and the Other (Durham, 1999).

33. Brian James Baer, "Now You See It: Gay (In)Visibility and the Performance of Post-Soviet identity,” in Nárcisz Fejes and Andrea P. Balogh, eds., Queer Visibility in PostSocialist Cultures (Bristol, 2013), 35-56.

34. An earlier version of this discussion was published on the LSE EUROPP European Politics and Policy blog, at http://blogs.lse.ac.uk/europpblog/2013/07/18/russia-homosexual-propaganda-ban (last accessed September 2, 2015).

35. President of Russia. 2014. Interv' iu rossiiskim i inostrannym SMI [Interview with Russian and Foreign Media]. Website of the President of Russia (last accessed December 28, 2016) at http://kremlin.ru/events/president/news/20080.

36. The full text is available on the Rossiyskaya Gazeta Dokumenty website: http:// www.rg.ru/2013/06/30/deti-site-dok.html (last accessed July 14, 2015).

37. Natalia Pecherskaya, "Perspektivy rossiiskoi semeinoi politiki: Prinuzhdenie k traditsii [Prospects for Russian Family Policy: The Drive towards Tradition]," Zhurnal Sotsiologii i Sotsialnoi Antropologii 69 (2013), 94-105, quotation on 96.

38. Cai Wilkinson, "Putting "Traditional Values" into Practice: The Rise and Contestation of Anti-Homopropaganda Laws in Russia," Journal of Human Rights, Special issue on Not Such an International Human Rights Norm: Local Resistance to Lesbian, Gay, Bisexual and Transgender Rights 13, no. 3 (2014), 368. 
part of a strategy to ensure the survival of the Russian nation. The survival of the physical nation would need a marked increase in the Russian birth rate, and to achieve this goal, according to Putin in a television interview in January 2014, Russia has to "cleanse" itself of gay people. ${ }^{39}$ To reinforce its specifically Russian identity, the nation needs to define itself against its main Other, the west-in particular, the United States and western Europe-rejecting their liberal values, including support for LGBQ equality.

While one might infer that the aim of the laws was to render homosexuality invisible, the top-down pressure from the state has to some degree inadvertently produced bottom-up counter-pressure in the form of a wave of new or renewed activism both within the country and beyond Russia's borders. The anti-LGBQ legislation has lit a fire under many Russian sexual dissidents, although the ability of activists within Russia to counter the homophobic political discourse is constrained by the very laws against which they are protesting. Nevertheless, the laws have also brought the issue of LGBQ rights in Russia-a topic the authorities sought to suppress-to national and international attention. The visibility that the legislation has unintentionally produced can thus be seen as an important component of resistance to the state-sponsored attempts to make homosexuality invisible in the public sphere.

Yet, while homosexuality has to some degree remained in the public eye, the othering of and increasingly hostile atmosphere for non-heterosexuals have prompted many homosexuals (outside of activist circles) to retreat to the private sphere or to gay and lesbian bars and clubs, which offer relatively safe spaces, albeit without "the infrastructure of community to nourish solidarity." ${ }^{\circ 0}$ As many of the respondents confirmed, however, not even the refuge of gay and lesbian bars and clubs was available outside of the major metropoles. Some towns and cities had never had an LGBQ venue, while in others they had been forced to close under pressure from the Church. Even if there were bars and clubs, access was often mediated by the economic capital of the clientele, making them out of reach for many. As Alyosha commented: "Gay establishments-the gay industry in general-are usually for well-off people, not for the poor." 41 Yet, even well-off respondents from major cities, such as St. Petersburg, reported that going to gay and lesbian clubs ran the risk of violence at the hands of both criminals and the police and was thus often avoided, with individuals preferring to make friends through personal contacts or on the Internet.

Outside of the "safe haven" of the home or LGBQ establishments, the behavior of respondents was thus constrained by fear of being identified as homosexual in the heterosexually-coded public space. As Alyosha explained: "I can't be seen on the street with a gay man. Although I can see that he's gay, I can't make friends with him or chat to him, because people would start to

39. “Putin: Russia must 'cleanse' itself of gays, but no need to fear in Sochi,” Aljazeera America, January 19, 2014 at http://america.aljazeera.com/articles/2014/1/19/putin-russia-mustcleanseitselfofgays.html (last accessed April 21, 2015)

40. Daniel Healey, "Russia," glbtq: An Encyclopedia of Gay, Lesbian, Bisexual, Transgender, and Queer Culture, at http://www.glbtqarchive.com/ssh/russia_S.pdf (last accessed September 3, 2015), 11.

41. Alyosha, interview, Berlin, March 23, 2012. 
look at me. They would start to talk." ${ }^{42}$ In general, what emerged from the data was that the ability to live one's life without fear of discrimination or physical violence largely depended on one's ability to remain invisible within society's heteronormative structures. For those who "do not look gay by Russian standards," to cite Boris, the ability "to pass" made life easier. ${ }^{43}$ For those unable to do so, even if they were not out to anyone, life was more difficult: "It wasn't ever possible to tell anyone. ... But you can tell that I am gay, I can't hide it, it's my nature. What am I supposed to do?"44

At some point in their lives, sexual minorities generally have to consider "what they are supposed to do"-how they should respond to situations in which they are constructed as not fitting within society, as being "out of place"-in ways that heterosexuals generally do not. The range of available responses is, of course, broadly culturally and historically contingent. One could argue that for sexual dissidents who do not wish to remain invisible in the public sphere (itself a choice that not all LGBQ people will wish to make or consider appropriate), or feel unable to remain invisible in the public sphere even if they wanted to, the basic response is one of "exit" or "voice" to use Albert Hirschman's classic paradigm..$^{45}$ In view of the fact that the regional and federal laws banning "propaganda of non-traditional sexual relations" have sought to stifle the voice of protesters, the decision to exit the homeland and move abroad has been an increasingly popular one. However, "exit" and "voice" must not be understood as mutually exclusive responses; rather, the former often leads to the latter. Indeed, it was as a result of migration to Berlin that many LGBQ Russians took part in coordinated protest activity against the government in Russia for the first time. As I will show later, this coordinated protest activity with activists in Russia was facilitated by the sense of identity, belonging and solidarity fostered by the Russian queer diaspora in Berlin.

\section{Queer Migration: Moving to Berlin}

While the western media often give the impression that gays and lesbians in the "illiberal east" are forced to migrate to the "liberal west" due to the intolerance towards homosexuality in their home societies, the picture painted by my respondents was far more complex. ${ }^{46}$ While sexuality did play a role in the migration decisions of almost all respondents, it was not always the primary motivating factor. Indeed, migration was not the preferred option for everyone and migration was not always expected to be permanent, even among

42. Alyosha, interview, Berlin, March 23, 2012.

43. Boris, interview, Berlin, April 3, 2012.

44. Alyosha, interview, Berlin, March 23, 2012.

45. Albert O. Hirschman, Exit, Voice, and Loyalty: Responses to Decline in Firms, Organizations, and States (Cambridge, Mass., 1970).

46. See "Gay Russians are seeking asylum in the United States because of anti-gay hostility and attacks in their homeland," Daily Mail, 29 November 2014: http://www.dailymail.co.uk/news/article-2854394/Gay-Russians-seeking-asylum-Unites-States-worsening-hostility-homeland.html (last accessed November 29, 2015); “Gay Poles head for UK to escape state crackdown,” The Guardian, 1 July 2007: http://www.guardian.co.uk/ world/2007/jul/01/gayrights.uk (last accessed June 16, 2012). 
those who did move to Berlin for reasons relating to their sexuality, which was not the case for all my respondents.

To Gorman-Murray, as discussed above, if migration by LGBQ migrants is not specifically motivated by issues related to sexuality, it is not queer migration. In his understanding of queer migration, Gorman-Murray therefore suggests a one-way relationship between sexuality and migration, with the former influencing the latter. I argue, however, that queer migration should be understood as a more dynamic, two-way process, whereby the experience of migration can also influence sexuality-the way it is understood, performed and experienced. If migration is “embodied displacement," as Gorman-Murray rightly suggests, queer migration should be understood as the displacement of queer bodies-whatever their motivation for migrating-and encompass a range of experiences, behaviors and feelings shared by queer migrants in contexts of displacement. ${ }^{47}$

In terms of destination, the choice of Germany by most respondents was largely determined by their ability to acquire German citizenship or residency. Three routes to citizenship or residency were identified. First, Germany offers preferential treatment in the acquisition of citizenship rights to migrants who are descended from the Germans who moved to Russia in the eighteenth century at the invitation of Catherine the Great. Spätaussiedler have enjoyed this legal right since $1953 .{ }^{48}$ Second, since 1991, Jews from the former Soviet Union have also enjoyed the right to migrate to Germany and obtain residence subject to their meeting certain conditions. ${ }^{49}$ (The emergence of the Russianspeaking diaspora in Berlin as a result of the initial waves of German-Russian and Jewish migration is discussed below.) All other migrants from the postSoviet space have no automatic entitlement to move to Germany and thus need to obtain student or working visas. As such, unless they have German or Jewish heritage, LGBQ migrants from the former Soviet Union need high cultural or economic capital to enter and remain legally in Germany, thus precluding those without the necessary education or financial resources. These three pathways to citizenship or residency map onto the three main social groups to which my respondents belonged: German-Russians; Russianspeaking Jews; and Russian businesspeople and students.

The choice of Berlin as a specific destination within Germany was based on a range of factors. First, the city was seen as being "more friendly towards immigrants" than other German cities and, because of the ethnic mix, "you don't feel like a foreigner." 50 Other respondents found Munich, for example, to be "too German." 51 Due, in part, to its multicultural character, Berlin is also known for being open to difference. As Zoya explained: "The liberalism and individuality of a city; it allows you to live your life on your own terms,

47. Andrew Gorman-Murray, "Intimate Mobilities," 445, emphasis added.

48. See the German Federal Law on Refugees and Exiles [in German]: http://www. gesetze-im-internet.de/bvfg/index.html (last accessed November 21, 2015).

49. Since 2005, Jewish migration from the former Soviet Union to Germany has been governed by the Immigration Act. The text of the law can be found at: http://dip21.bundestag.de/dip21/btd/15/004/1500420.pdf (last accessed November 21, 2015).

50. Boris, interview, Berlin, April 3, 2012.

51. Masha, interview, Berlin, May 2, 2012. 
much more so than in a small town. For me, Berlin is unique in Germany, it's different, much freer." ${ }^{2}$ Both the freedom and openness to difference were repeatedly mentioned with particular reference to sexuality. This related in part to the LGBQ scene in Berlin, which was a pull factor for a number of respondents, but more often to the relaxed attitudes of Berliners towards LGBQ people, in general. As Boris recounts: "When I was in Russia, I had my own firm and earned enough to go travelling. I saw many countries and saw how people lived and how other societies treat gay people.... Therefore I set myself the goal of living in a city, in a country, where you don't have to hide your orientation, you don't have to be afraid of anything and where you can be who you want to be. That's why I moved here [Berlin]." 53 While the above factors would potentially be a pull for all LGBQ migrants, it was the specific history of Berlin that acted as an additional draw for some of the migrants from the former USSR. For Masha it was the Soviet influence on the architecture and urban landscape of Berlin that appealed, that provided a sense of familiarity: "As I've always said, Berlin has so much of my past in it."54 For Zoya, it had more to do with the fusion of the city's eastern and western character, which reflected her identification with both the east and the west: "It's the unbelievably unique character of this city that was divided and then joined together. I like that. Growing up in Russia and moving to western Europe ... there was this huge rift between two worlds. And in Berlin I have somehow been able to bring these two worlds together, so that they are no longer in opposition." 55

As discussed above, in terms of motivation, the academic literature suggests that the main reason for migrating is economic: individuals move to boost their wages and gain work experience. ${ }^{56}$ For many LGBQ migrants, however, economic considerations are secondary, if they are considered at all. While it would be incorrect to say that economic factors played no role in the migration decision of my respondents in that some used their economic capital to finance their move to Germany, only one respondent stipulated that he had migrated with the specific aim of improving his career prospects. Two of my respondents owned their own businesses in Russia and Kazakhstan, respectively, and reported that they earned a good living. According to neo-classical economic theories of migration, they would have been better off staying at home; yet, they chose to move to Germany. For all but two of the respondents who had migrated as adults, that is, not as children with their parents, the decision to move abroad had been motivated at least in part by their sexuality. It is important to stress, however, that sexuality was not always the primary reason, as Vladimir explains:

"There were a number of reasons at that time why I wanted to move abroad, not necessarily to Germany, but abroad. Of course, one reason was my sexual identity. There were also other reasons that were also important. So my sexual identity and my coming out weren't the main reasons." 57

52. Zoya, interview, Berlin, April 25, 2012.

53. Boris, interview, Berlin, April 3, 2012.

54. Masha, interview, Berlin, May 2, 2012.

55. Zoya, interview, Berlin, April 25, 2012.

56. Stark and Bloom, "The New Economics of Labor Migration."

57. Vladimir, interview, Berlin, April 11, 2012. 
In terms of specific motivations, for most respondents migration was "a means of escape and of self-realization," to quote Jon Binnie. ${ }^{58}$ While one respondent came to Germany as an asylum-seeker, fleeing Kazakhstan in fear for his life, for the others the decision to migrate was not driven by the need to escape physical violence, as their invisibility, restriction to the private sphere, or their economic capital largely shielded them from potential attack. ${ }^{59}$ Rather, they chose to leave their homelands to escape the heteronormative mechanisms of social control in order to live their lives openly and enjoy rights denied to them at home due to their sexual orientation. This desire for sexual citizenship rights must then be added to Gorman-Murray's threepart classification of motivations for queer migration, discussed above. ${ }^{60}$

Prior to emigrating, less than one third of my respondents had come out and, of those who were out, very few were out to their families. Fear of their parents' reactions and/or fear of trouble at work or college prevented them from being open about their sexual orientation with anyone other than their closest friends. Boris's case was typical: "The only people who knew I was gay were gay themselves. My colleagues didn't know I was gay, my parents didn't know I was gay, my straight friends didn't know I was gay."61 For Ivan, who lived at home with his parents in a small village, the choice he faced-if he decided to stay in Russia-was between coming out and possibly losing his family or staying in the closet and maintaining a relationship with his parents. Migration offered him the opportunity to come out and live his life as a gay man, without his parents finding out: "My family is important to me, so I couldn't [come out at home], that wasn't possible. It was only after I moved to Cologne [before then moving to Berlin] that I started to live for myself, that I started to live." 62

It is important to stress, however, that moving abroad was not always the respondents' first choice; for some staying in their home country would have been preferred. As Zoya explained, her main aim was for her and her girlfriend to escape the social pressure of their provincial home town, which they hoped could be achieved by means of internal migration: "We were feeling pressure from society, on the one side, and pressure from our families, acquaintances, colleagues, friends of our parents. There was a lot of pressure from the family. In a large city, you can simply move to another part of town. But living in a small town-that's difficult. We wanted to live together. So our idea was simply to move to St. Petersburg." ${ }^{63}$ While migration to a Russian metropolis with at least some LGBQ establishments provided a space to meet other LGBQ people and possibly "explore bodily sexual desires," it is difficult to consider this a case of "gravitational group migration" in the sense Gorman-Murray uses it in that the "community belonging" and "sense of ease in performing

58. Binnie, “Invisible Europeans,” 240.

59. For a photographic representation of gay men who fled Russia and sought asylum in the United States on the grounds of their sexual orientation, see Alexander Kargaltsev, Asylum (New York, 2012).

60. Andrew Gorman-Murray, "Intimate Mobilities,” 446.

61. Boris, interview, Berlin, April 3, 2012.

62. Ivan, interview, Berlin, April 25, 2012.

63. Zoya, interview, Berlin, April 25, 2012. 
embodied sexualities"-at least in the public sphere-were missing from my respondents' accounts of LGBQ life in post-Soviet metropolitan spaces. ${ }^{64}$

An additional frequently-mentioned motivation for migrating was to be able to live with one's partner, with the assumption being that "attitudes towards same-sex couples would be better" in Germany ${ }^{65}$ For a number of respondents, one partner had succeeded in using their cultural capital to obtain a scholarship to study at a university in Germany, which enabled them to support the immigration of the other. However, it is important to point out that not all respondents intended to stay away from Russia permanently, as was the case with Zoya. As she went on to explain, it was only once she and her partner had lived in Germany for a while that she became aware of the differences between the two countries in terms of being able to live one's life openly, subsequently making it more difficult to leave: "Once you have tasted this freedom, you do not want to lose it." ${ }^{\text {"6 }}$ This point was also made by others, such as Polina, who linked this sense of freedom to greater legal rights, acknowledging that it was in Berlin that she first understood she, as a lesbian, had rights, just like everyone else. While sexual citizenship rights were not specifically mentioned as pull factors by many other respondents, a number of them had entered into civil partnerships and/or adopted their same-sex partners' children, rights that would have been unavailable to them in their home countries. The differences between Germany and Russia came into even sharper relief for those, such as Leonid and Darya, who lived transnational lives between Germany and Russia. For Darya, it had been the stress of "living normally here in Berlin" but "not having a private life" when working in Russia that eventually prompted her to move to Berlin permanently. ${ }^{67}$ Therefore, even for those for whom their sexuality was not a key reason to leave, it was often a key reason to stay, as confirmed by Olga: "I would say that [my sexuality] played perhaps a subconscious role in my decision to migrate, but in my decision to stay here-absolutely." 68

\section{Queer Diaspora: Renegotiating Russianness}

While the general impression given by my respondents-even those who were not initially keen to move to Germany or did not move for reasons related to their sexuality-was that they felt greater freedom to perform their sexuality and develop relationships with other non-heterosexuals in Berlin than in their home countries. It was also clear that the communities of belonging that LGBQ migrants seek out are not defined exclusively with relation to sexual orientation. Despite the political attempts to construct homosexuality and Russian national identity as being mutually exclusive, it was apparent from the interviews that Russianness-particularly with reference to Russian language, culture and mentality-was a central part of the sense of self of almost all my respondents.

64. Andrew Gorman-Murray, “Intimate Mobilities,” 450.

65. Polina, interview, Berlin, May 30, 2012.

66. Zoya, interview, Berlin, April 25, 2012.

67. Darya, interview, Berlin, April 18, 2012.

68. Olga, interview, Berlin, May 30, 2012. 
It is important to stress that the respondents' identification with Russianness was not necessarily predicated upon their being ethnically Russian; this appeared particularly to have been the case with non-Russian Slavs and for members of ethnic groups that did not have an eponymous Soviet republic or were geographically dispersed across the territory of the USSR. The USSR's policy of requiring all citizens to learn Russian and the frequent conflation of Soviet and Russian culture produced subjects who often considered themselves culturally Russian, even if they were ethnically Ukrainian, Belarusian, Jewish, or German. As Katya, who was born and brought up in Ukraine, explained with reference to the mixing and blurring of her Ukrainian and Russian heritage: "Well, I was born in the Soviet Union, so there was never a specific distinction between Ukraine and Russia." ${ }^{69}$ At the same time, respondents recognized that their sense of Russianness was often just one of a "palette of identities" that changed as their "priorities changed". ${ }^{70}$ Nevertheless, while many had been acculturated into a range of identity groups and could therefore function unproblematically in a range of cultural contexts, all but one resisted completely losing their sense of Russianness, which was understood to shape "the way I'm thinking, the way I'm talking, the behavior, the values," to quote Evgeniy. ${ }^{71}$

The ability to speak Russian with other native-speakers was identified by respondents as particularly important. For Sonya, it played an important role in shaping her self-identification as Russian, despite neither of her parents being ethnically Russian. While for some the desire to speak Russian was related more to their inability to communicate very well in German in the initial post-migration period, for others it had more to do with the comfort of "switching off your brain" or being able to use language in a more sophisticated manner than would be the case with German. ${ }^{72}$ It is, of course, important to remember that language is not simply a functional means of communication but also the means to convey a wealth of meanings and cultural references. Together, Russian-speakers can share jokes, without having to provide context. The Russian language thus provided a common denominator for many of the respondents, enabling individuals from different parts of the former USSR, for example, to reminisce about their childhoods, the children's TV shows they used to watch, and the songs they used to sing. As Olga recalled: "It does not matter if you are from Uzbekistan or Russia, you all had the same two TV channels and sang the same songs." 73

This shared socialization into the norms of Soviet society also produced what was frequently referred to as a "Russian mentality," an important aspect of Russianness that distinguished them from Germans. A key aspect of this mentality was the perception that Russians are governed more "by emotion than reason" and that they take more of an interest in others than do other nationalities. ${ }^{74}$ While in extemis this could be seen as a problem, as Russians

69. Katya, interview, Berlin, April 25, 2012.

70. Darya, interview, Berlin, April 18, 2012.

71. Evgeniy, interview, Berlin, April 24, 2012.

72. Yuriy, interview, Berlin, July 31, 2012.

73. Olga, interview, Berlin, May 30, 2012.

74. Galina, interview, Berlin, April 16, 2012. 
"tend to stick their noses in everywhere," it was generally understood as the desire of Russians to make personal connections with others and was thus seen as a factor enhancing well-being and a sense of belonging. ${ }^{75}$ Indeed, the perceived standoffishness of Germans was seen by some, such as Galina, as a cause of feelings of isolation: "Initially, I tried really hard to integrate into this society but, for some reason, it was difficult. I found them [Germans] not as warm-hearted as Russians. Perhaps, that is just a stereotype but I found it to be true."76 For Olga, the fear that the freedom that Berlin offered to LGBQ migrants could potentially be offset by a sense of loneliness were she to leave behind her Russian-speaking friends and family weighed on her decision as to whether she should migrate at all: "I must admit that there was a thought somewhere in the back of my mind: when I am in Berlin, I will be free for the first time in my life to do whatever I want ... if I go. Because I had the feeling that I would be completely alone. I am the only one like this-especially among Russian-speakers."77

What the above discussion shows is that sexual identity is not the only identity that is important to LGBQ migrants and that national identity plays a key role in their self-identification, their ability to make sense of the world, and their personal well-being. Moreover, Russianness was not understood as an individual sense of self, which could be sustained on one's own, but rather as emerging out of interaction with others. In attempting to maintain a sense of national identity in the post-migration context, migrants often seek out people of their own ethno-cultural background in the destination society. Diasporas thus play an important role in that they often "mobilize a collective identity," thereby creating a sense of community and solidarity with co-ethnic members within and across state boundaries, and provide economic, social, and psychological support. ${ }^{78}$ As discussed above, I argue that "diaspora" must be understood as both a social form and a form of consciousness, critiquing the traditional conceptualization as a rigidly-demarcated, bounded community, defined exclusively with reference to an ethnic homeland and with a shared identity and joint interests. Below I assess the extent to which a cohesive Russian-speaking diaspora community in Berlin can be said to exist and whether the latter provided a sense of identity, solidarity, and belonging for the LGBQ migrants.

Germany is home to the largest population of Russian-speakers outside of the former USSR. Precise figures are unavailable, however; as soon as they are granted German citizenship (for which Spätaussiedler and Jews from the former Soviet Union are given preferential treatment), they are not counted as anything other than German in official statistics. It is known, however, that over 1.5 million ethnic Germans from the former Soviet republics emigrated to Germany between 1992 and 2007, with some 100,000 Jews arriving during the nineties. ${ }^{79}$ It is estimated that around 300,000 Russian-speakers live in Berlin alone, with the largest concentration found in Marzahn-Hellersdorf, a socially

75. Masha, interview, Berlin, May 2, 2012.

76. Galina, interview, Berlin, April 16, 2012.

77. Olga, interview, Berlin, May 30, 2012.

78. Cohen, Global Diasporas, 7.

79. Wolfgang Kil and Hilary Silver, "From Kreuzberg to Marzahn: New Migrant Communities in Berlin," German Politics and Society 24, no. 4 (Winter 2006), 103. 
disadvantaged district in the east of the city. ${ }^{80}$ The earliest Spätaussiedler were provided with apartments by the authorities in the housing estates on the edge of the city, while later waves of German-Russians who had to make their own arrangements also headed to Marzahn-Hellersdorf as they "preferred living among their compatriots." ${ }^{81}$ Ethnographic researchers found that in this residential enclave the German-Russians lived closely together in "vertical villages: high-rise buildings completely settled by immigrants of one national origin," where Russian remained the dominant language of communication and a range of restaurants, businesses, and cultural venues catered to the sizeable Russian-speaking population. ${ }^{82}$ Ethnic density together with the existence of ethnic commercial and cultural spaces are generally the sine qua non for the development of a diaspora community as a social form, enabling members to speak their language, perform their culture, and maintain the collective identity-or, at least, a specific conceptualization of the collective identity. Research into various diaspora communities has demonstrated that, as a strategy aimed at avoiding assimilation into the host society, the former often promote a more traditional understanding of the shared identity, norms, and values-especially regarding gender and sexuality-than is the case in the homeland they left behind. ${ }^{83}$ This is particularly true if there is limited integration and rigid boundary-maintenance on the part of the diaspora, which, according to a number of my respondents, is the case with many Russian-speakers in Berlin. As Vladimir suggests: "There are many Russian Jews and many German-Russians and they are very closed communities." 84 As Galina argues, by "living in ghettos" and "only mixing with other Marzahn Russians," the Russian-speaking migrants can live their lives as if they never left Russia: "I can only imagine that the older generation think they are still there." ${ }^{85}$ Given that attitudes towards sexual minorities in Russia and other post-Soviet states are generally negative, Russian-speaking migrants often bring their "Soviet experiences, attitudes, and prejudices regarding homosexuality" with them to Germany. ${ }^{86}$ While research has shown that migration can under certain conditions liberalize attitudes towards homosexuality, this is less likely to be the case if there is limited integration into the host society. ${ }^{87}$ This was the experience of Katya, who had migrated to Germany as a child with her family. After migrating, the family only watched Russian TV and read the Russian press, only spoke Russian, had little contact with Germans, and their circle of acquaintance was limited to "compatriots," as she put it. ${ }^{88}$

80. Zlata Bossina, "Politisch wider Willen Russisch in Berlin: Queer + Art = Quarteera," Osteuropa 10 (2013), 119.

81. Wolfgang Kil and Hilary Silver, "From Kreuzberg to Marzahn,” 103.

82. Ibid., 109.

83. See, for example, Carol Goodenow and Olivia M. Espin, "Identity Choices in Immigrant Adolescent Females,” Adolescence 28, no. 109 (1993): 173-84.

84. Vladimir, interview, Berlin, April 11, 2012.

85. Galina, interview, Berlin, April 16, 2012.

86. Bossina, "Politisch wider Willen," 119.

87. Richard C. M. Mole, Christopher J. Gerry, Violetta Parutis and Fiona M. Burns, "Migration and Sexual Resocialisation: The Case of Central and East Europeans in London," East European Politics and Societies and Cultures 31, no. 1 (2017): 201-22.

88. Katya, interview, Berlin, April 25, 2012. 
When she came out to her family, the attitudes towards homosexuality they had imported from the former Soviet Union resulted in their cutting off all contact with her. Alyosha, an asylum-seeker, was wary of coming across other Russians, for similar reasons: “I wasn't afraid of foreigners, I wasn't afraid of people from Ethiopia or from Iran, because they have their culture and I have mine.... I was very afraid of Russian-speakers, that they would come up to me and ask me: who are you, what are you, are you gay or not gay, what are you doing here?" 89

While not all migrants are necessarily keen to be part of their ethno-cultural diaspora community, they may still define their identities with reference to the ethnic homeland and visit diasporic spaces to enjoy their national culture, traditions, and cuisines, that is, they have a "diaspora consciousness." 90 Yet, even for those who sought to limit their involvement with the diaspora to visiting diasporic spaces, a number of respondents felt these spaces to be unwelcoming to LGBQ people, or that the form of representation of Russianness being propagated was unappealing. Vladimir stopped visiting "traditional restaurants, where there are Russians and only Russians," for example, as he was made to feel unwelcome because of his sexuality. ${ }^{91}$ Similarly, Boris only attended one "Day of Russian Culture" (an annual event, comprising Russia-related talks, films and art exhibitions) because of the behavior of the members of the ethno-cultural diaspora: "It reminds me of the Russia I left behind. Drunk, uncivilized people, swearing-exactly what I wanted to escape from." 92 Other respondents, such as Darya, objected to the very traditional and fixed understanding of Russianness propagated by the Russian Embassy and Russia House, which failed to take account of alternative cultural perspectives: "What the Embassy and Russia House do in terms of culture is so absolute. This is authentic Russian culture.... It's true that there are Goethe Institutes in other countries and they propagate German culture but it's not just Goethe and Schiller but much more. It is more varied."93

While the interviews revealed that almost all respondents were keen to maintain a sense of Russianness as part of an ethno-cultural community, the Russian ethno-cultural diaspora and diasporic spaces in Berlin were perceived to be unappealing or unwelcoming for those identifying as LGBQ. Problematizing the idea that shared ethno-cultural identity is sufficient to create a sense of "we" feeling within the diaspora community as a whole, the pre-existing Russian diasporic ethnoscape did not meet the need among the respondents for queer-friendly spaces. It was recognition of the fact that being "a migrant and LGBT" could lead to "double discrimination" that prompted the establishment of Quarteera, an association of LGBT Russian-speakers and their friends. ${ }^{94}$ The aims of Quarteera are to act as an organization to represent the interests of Russian-speaking gays and lesbians in Berlin, to coun-

89. Alyosha, interview, Berlin, March 23. 2012.

90. Steven Vertovec, “Three Meanings of 'Diaspora,' Exemplified among South Asian Religions,” Diaspora: A Journal of Transnational Studies 6, no. 3 (Winter 1997), 281.

91. Vladimir, interview, Berlin, April 11, 2012.

92. Boris, interview, Berlin, April 3, 2012.

93. Darya, interview, Berlin, April 18, 2012.

94. Polina, interview, Berlin, May 30, 2012. 
teract the homophobia in the Russian ethno-cultural diaspora, to provide a space to discuss personal problems relating to sexuality, protest against the homophobic policies of the Russian government, and to support LGBT activists in Russia. ${ }^{95}$ In this sense, it could be understood simply as a social movement. If we are to understand the affective appeal of Quarteera to its members, however, the role it plays as a specifically Russian space, the social and psychological support it offers its members, the desire of its members to change the socio-political situation in Russia, and the sense of solidarity they feel towards LGBQ people in the "homeland," I argue that we need to recognize Quarteera as a form of "queer diaspora," albeit a form that challenges existing conceptualizations in the academic literature.

While understanding queer diaspora as the diasporization of queer culture and politics is a useful way of conceptualizing transnational networks of LGBQ political activists-among whose number Quarteera has many"privileging sexuality," rather than ethnicity, as the "primary 'identity' throughout the diaspora" runs the risk, for example, of western/non-western hierarchies being produced within the supposedly ethno-neutral global queer diaspora. ${ }^{96}$ This was the experience of one Quarteera member's co-operation with a German LGBT organization, which attempted to teach him how to do activism, despite his many years of fighting for LGBT rights in Russia. While Fortier's understanding of queer diaspora as "the creation of queer spaces within ethnically-defined diasporas" in the context of Russian-speaking LGBQ in Berlin would apply to diaspora as a form of consciousness, it assumes a willingness on the part of the ethno-cultural diaspora as a social form to create a space for non-heterosexuals, which is not necessarily the case. ${ }^{97}$ For this reason, I argue that "queer diaspora" is better understood as a community of migrants as a social form, united by shared sexual as well as ethno-cultural identities, which operates not necessarily within but also outside (or largely outside) the larger ethno-culturally defined diaspora.

The benefit of understanding Quarteera as a form of queer diaspora will become clear, when we examine the roles that it plays in terms of providing social and psychological support to the Russian-speaking LGBQ community in Berlin as well as solidarity with other LGBQs in the post-Soviet space. First, it provides a space where non-heterosexual Russian-speakers can meet other non-heterosexual Russian-speakers and are free to perform their sexual identities in a specifically Russian-speaking environment. As Leonid reminisced: "Only in the past two years, thanks to the people who organized Quarteera, do I have Russian friendships that are stable. And in part this has to do with the ability to be open [about my sexuality]." ${ }^{98}$ For Katya, Quarteera offered the psychological support of community she needed after her family disowned her after she came out to them. Having gone through this experience, she felt a sense of responsibility to others in the same situation. While there are various

95. Bossina, "Politisch wider Willen," 118-19.

96. Rogers Brubaker, "The 'Diaspora' Diaspora,” 12; Gayatri Gopinath, "Funny Boys and Girls: Notes on a Queer South Asian Planet," in Russell Leong, ed., Asian American Sexualities: Dimensions of the Gay and Lesbian Experience (New York, 1996), 123.

97. Fortier, “Queer Diaspora,” 183.

98. Leonid, interview, Berlin, May 2, 2012. 
German organizations and support networks aimed at LGBQ individuals, they lack the affective appeal of Quarteera. As Olga explained, Russian-speaking "individuals and their families can go and receive support" from people who not only speak Russian but also understand the socio-cultural factors underlying the conflict; due to the linguistic and cultural specificities of the Russian-speaking community, "these people cannot be helped in a 'normal' German-speaking association."99

Quarteera is also active in protesting against the situation for LGBQ people in Russia and other post-Soviet states. Analyzing its actions through the prism of "queer diaspora" helps us understand how the shared sexual and ethno-cultural identity, oriented towards the (former) homeland, facilitates its ability "to make claims, articulate projects, to formulate expectations, to mobilize energies, to appeal to loyalties” among Russian-speaking queer migrants in Berlin. ${ }^{100}$ Likewise, the participation of Quarteera in a Rainbow FlashMob, whereby individuals simultaneously release rainbow-colored balloons in towns and cities across the world to mark the International Day against Homophobia and Transphobia, was understood by Zoya as "an action of solidarity" with LGBT people in various post-Soviet states. ${ }^{101}$ While many of the LGBQ Russian-speakers were part of a globalized queer politics, taking part in protests against the LGBT rights situation in Russia and other postSoviet states, this feeling of solidarity with LGBQ Russians derived as much from their shared ethno-cultural identity as their shared sexual identity.

The above discussion constitutes one of the few empirically-grounded analyses of cross-border migration by LGBQ individuals in Europe. On the basis of extensive fieldwork in the form of participant observation and indepth interviews, the article furthers our understanding of queer migration by analyzing the motivations and migration strategies of LGBQ Russian-speakers in Berlin as well as their attempts to maintain and perform their identities, and seek out communities of belonging in the post-migration context. It challenges the dominant neo-classical economic explanation for migration and highlights the importance of incorporating sexuality as an explanatory factor in the decisions of non-heterosexuals to move abroad. Contrary to assumptions made by the western media about east European gays and lesbians desperate to flee the "illiberal east" for the "liberal west," the research also identified feelings of ambivalence and resistance among some respondents about their decision to move abroad, despite the differences in legal rights for and social attitudes towards sexual minorities in the post-Soviet space and Germany. The article also challenges existing understandings of queer migration that posit a one-way relationship between sexuality and migration, with the former influencing the latter, in favor of a more dynamic interplay between the two concepts. Queer migration, I argue, is better understood as the movement of queer bodies through space, encompassing a range of experiences, behaviors and feelings shared by queer migrants in contexts of displacement, even if sexuality was not a motivating factor in their decision to move abroad.

99. Olga, interview, Berlin, May 30, 2012.

100. Brubaker, “The 'Diaspora' Diaspora,” 12

101. Zoya, interview, Berlin, April 25, 2012. 
My findings also suggest that sexual identity is not the only identity that is important to LGBQ migrants and that-despite political attempts to construct non-heterosexuals as being outside the nation-national identity can play a key role in their self-identification, their ability to make sense of the world as well as their personal well-being, challenging the idea that queers in contexts of displacement feel no attachment to their national homelands. The interplay between sexuality and migration helps us understand queer migrants' attempts to seek out communities of belonging defined in ethno-national terms to "mobilize a collective identity," create a sense of community and solidarity with co-ethnic members within and across state boundaries, and provide economic, social, and psychological support. It is thus to the development of our understanding of the interplay between diasporic and sexual identities that the article makes a particular contribution.

Without suggesting that all diasporic communities are unwelcoming to the LGBQ members of their communities, my findings suggest that, if there is limited integration or rigid boundary-maintenance on the part of the ethnonational diaspora (which, according to a number of my respondents, is the case with many Russian-speakers in Berlin), it will be very difficult for queer migrants to find a space in the pre-existing diasporic ethnoscape. The experience of my respondents demonstrated that the shared homeland orientation and sense of Russianness were insufficient to create a sense of "we" feeling within the diaspora community as a whole in that the latter was perceived as unwelcoming or unappealing to many LGBQ Russophones.

Recognition that LGBQ migrants risked being doubly marginalizedas ethnic minorities within the host society and sexual minorities within the co-ethnic diasporic community-prompted the creation of Quarteera. While it could be described simply as a social movement, the role Quarteera plays as a forum for performing and maintaining both sexual and ethnocultural identities, its provision of social and psychological support to its members, its orientation towards the post-Soviet homeland, and the feelings of solidarity it expresses towards other Russian-speaking queers have an affective quality that can best be understood with reference to diaspora. Problematizing the traditional understanding of diaspora solely as a rigidly-demarcated, bounded community, defined exclusively with reference to an ethnic homeland, with a shared identity and joint interests, my findings thus showed that diaspora can be used flexibly and applied to migrant communities defined not exclusively in ethnic terms but also defined with reference to sexuality.

While I argue in favor of the potential benefit of using "queer diaspora" as a heuristic device to think about identity, belonging, and solidarity among sexual minorities in the context of dispersal, I critique the conceptualization of queer diaspora as the diasporization of ethno-culturally neutral queer communities, as emptying the queer diaspora of its ethno-cultural content weakens the latter's affective appeal and runs the risk of reproducing western/non-western hierarchies. At the same time, understanding "queer diaspora" as "the creation of queer spaces within ethnically-defined diasporas" assumes a willingness on the part of ethno-cultural diaspora to create a space 
for non-heterosexuals, which is not necessarily the case. ${ }^{102}$ For this reason, this research calls for the concept of "queer diaspora" to be rethought of as a community of migrants as a social form, united by shared sexual as well as ethno-cultural identities, which operates not necessarily within but also outside (or mostly outside) the larger ethno-culturally defined diaspora. In this connection, a potential benefit of ethno-cultural queer diasporas to be explored in future research relates to their ability to minimize western homonationalism, that is, "the use of 'acceptance' and 'tolerance' for gay and lesbian subjects as the barometer by which the legitimacy of and capacity for national sovereignty is evaluated." 103 If "western" criticism of the situation in Russia is by individuals and groups of the same ethno-cultural community, it would thus limit the potential for western/non-western hierarchies to be constructed.

102. Fortier, “Queer Diaspora,” 183.

103. Jasbir K. Puar, "Homonationalism as Assemblage: Viral Travels, Affective Sexualities," Jindal Global Law Review 4, no. 2 (November 2013), 24. 